\title{
Benzodiazepine premedication may attenuate the stress response in daycase anesthesia: a pilot study
}

\author{
[La prémédication avec de la benzodiazépine peut diminuer la réaction de stress \\ en chirurgie d'un jour : une étude pilote]
}

Michelle Duggan ffarcsi, ${ }^{*}$ Noreen Dowd ffarcsi, ${ }^{*}$ Denise O’Mara Rn Mba, ${ }^{*}$ Dominic Harmon ffarcsi, William Tormey FRCPI, $\dagger$ Anthony J. Cunningham MD FRCPC*

Purpose: Patients undergoing daycase surgery suffer from varying degrees of fear and anxiety. There is conflicting evidence in the literature regarding the benefit of benzodiazepine premedication in daycase surgery. We carried out a prospective, double-blind, randomized pilot study investigating the effect of benzodiazepine premedication on the stress response in patients undergoing daycase anesthesia and surgery.

Methods: Group I $(n=16)$ received diazepam $0.1 \mathrm{mg} \cdot \mathrm{kg}^{-1}$ orally 60 min preoperatively; Group II $(n=15)$ received diazepam 0.1 $\mathrm{mg} \cdot \mathrm{kg}^{-1}$ orally 90 min preoperatively; Group III $(n=30)$ received a placebo. The stress response was measured by analyzing urinary catecholamine and cortisol levels and by scoring anxiety levels using state-trait anxiety inventory (STAI) scores and visual analogue scores (VAS).

Results: Anxiety scores (VAS and STAI scores) were not different between groups. We found a statistically significant reduction in urinary cortisol and noradrenaline levels in the groups receiving diazepam vs placebo.

Discussion: The reduction in stress hormones following diazepam premedication, in patients undergoing daycase surgery may support the role for benzodiazepine premedication in this setting. However, further studies are warranted to determine the clinical significance of these findings.

Objectif : Les patients de chirurgie d'un jour éprouvent des craintes et de l'anxiété à divers degrés. La documentation scientifique présente des arguments contradictoires concernant les bienfaits de la prémédication aux benzodiazépines en chirurgie d'un jour. Nous avons réalisé une étude pilote prospective, randomisée et à double insu pour vérifier l'effet de la prémédication à la benzodiazépine sur la réaction de stress chez des patients anesthésiés en chirurgie d'un jour.
Méthode : Les patients du Groupe I $(\mathrm{n}=16)$ ont reçu $0,1 \mathrm{mg} \cdot \mathrm{kg}^{-1}$ de diazépam oralement 60 min avant l'opération ; ceux du Groupe II $(n=15)$ ont eu $0,1 \mathrm{mg} \cdot \mathrm{kg}^{-1}$ de diazépam oralement 90 min avant l'opération et ceux du Groupe III ( $n=30)$, un placebo. La réaction de stress a été mesurée en analysant les niveaux de catécholamine et de cortisol urinaires et en cotant le degré d'anxiété à l'aide du questionnaire sur l'anxiété chronique et réactionnelle STAI (state-trait anxiety inventory) et l'échelle visuelle analogique (EVA).

Résultats : Les scores d'anxiété (EVA et STAI) ont été comparables d'un groupe à l'autre. II existait une réduction statistiquement significative de cortisol et de noradrénaline urinaires chez les patients qui ont reçu du diazépam vs le placebo.

Discussion : La réduction des hormones de stress qui suit la prémédication avec du diazépam chez les patients de chirurgie d'un jour peut encourager la prémédication avec des benzodiazépines dans ce contexte. Toutefois, la valeur clinique de ces résultats doit être précisée.

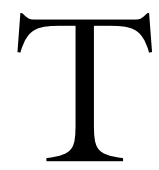

HE number of procedures performed as day (ambulatory) surgeries has increased significantly in recent years. Undoubtedly, the practice of day surgery will increase worldwide given its excellent safety record and its potential to reduce health care costs. ${ }^{1}$ Daycase surgery necessitates an anesthetic technique associated with minimal morbidity and rapid recovery. ${ }^{2,3}$

In common with all patients who await surgery, patients undergoing daycase surgery suffer from varying degrees of fear and anxiety. Mackenzie reported that mean anxiety visual analogue scores across all age groups (16-65 yr) was 46.7 (42.4-51.0) in 200 patients undergoing daycase surgery. ${ }^{4}$ There is conflicting evidence in

From the Department of Anaesthesia, ${ }^{*}$ and Chemical Pathology, $†$ Beaumont Hospital, Dublin, Ireland.

Address correspondence to: Dr. Michelle Duggan, Department of Anaesthesia, The Hospital for Sick Children, 555 University Avenue,

Toronto, Ontario M5G 1X8, Canada. Phone: 416-813-7445; Fax: 416-813-7543; E-mail: mduggan@sickkids.on.ca

Accepted for publication December 11, 2001.

First revision accepted April 18, 2002.

Second revision accepted July 10, 2002. 
the literature regarding the benefit of benzodiazepine premedication in daycase surgery. The administration of short-acting benzodiazepines has been shown to allay anxiety and reduce the dose requirements of anesthetic agents without prolonging recovery time. ${ }^{2,5}$ However, the relatively slow onset and long duration of action, with consequent hangover effects of some benzodiazepines, may reduce the suitability of these drugs for use in daycase surgery. In addition several investigators reported little difference in anxiolytic effects between benzodiazepines and placebo. ${ }^{6,7}$

We conducted a pilot, prospective, double-blind, randomized study to investigate the effect of benzodiazepine premedication on the stress response in patients undergoing daycase anesthesia and surgery.

\section{Patients and methods}

Sixty-one patients admitted for elective daycase surgery were enrolled into the study. Inclusion criteria included male and female patients, ranging from 18 to $65 \mathrm{yr}$, of ASA physical status I-III. Patients with a history of renal disease, benzodiazepine allergy or other sedative medication were excluded.

After Institutional Ethics Committee approval and informed consent, patients were randomly allocated to one of three groups. Randomization was performed using a random numbers table by the research division, pharmacy, Beaumont Hospital. The groups were as follows: Group I $(n=16)$ received diazepam 0.1 $\mathrm{mg} \cdot \mathrm{kg}^{-1}$ orally $60 \mathrm{~min}$ preoperatively; Group II $(n=$ 15) received diazepam $0.1 \mathrm{mg} \cdot \mathrm{kg}^{-1}$ orally $90 \mathrm{~min}$ preoperatively; Group III $(n=30)$ received a placebo.

The perioperative stress response was evaluated by measuring anxiety scores and urinary catecholamine and cortisol levels at three time points - Tl (before any premedication), T2 (immediately before entering the operating room) and T3 (before leaving hospital).

Anxiety scores were measured using a state-trait anxiety inventory (STAI) score ${ }^{8}$ and a visual analogue score (VAS) for anxiety. Spielberger's STAI is an established measure of anxiety. The state form of the STAI is a measure of how the person feels "right now" whereas the trait form refers to anxiety proneness. Urinary free catecholamines were measured on stat urine samples at $\mathrm{T} 1, \mathrm{~T} 2$ and $\mathrm{T} 3$.

The anesthetic technique was standardized for all patients in the study. Anesthesia was induced with fentanyl $1 \mu \mathrm{g} \cdot \mathrm{kg}^{-1}$ and propofol $2 \mathrm{mg} \cdot \mathrm{kg}^{-1}$ intravenously. A laryngeal mask was inserted and anesthesia was maintained with the patient breathing spontaneously a mixture of oxygen in nitrous oxide and isoflurane $(0.5-2 \%)$. Standard anesthetic monitoring was used in each case including electrocardiogram, pulse oximetry,
TABLE I Patient characteristics

\begin{tabular}{llll}
\hline & $\begin{array}{l}\text { Group I } \\
\text { 60 min } \\
\text { treatment } \\
\text { group }\end{array}$ & $\begin{array}{l}\text { Group II } \\
\text { 90 min } \\
\text { treatment } \\
\text { group }\end{array}$ & $\begin{array}{l}\text { Group III } \\
\text { placebo group }\end{array}$ \\
\hline Number $(n)$ & 16 & 15 & 29 \\
$\begin{array}{l}\text { Male/female ratio } \\
\text { Age (yr) }\end{array}$ & 34.8 & $7 / 8$ & $12 / 17$ \\
$\begin{array}{l}\text { Weight (kg) } \\
\begin{array}{l}\text { Duration of surgery } \\
\text { (min) }\end{array}\end{array}$ & $43.8 \pm 11.2$ & $38.4 \pm 11.9$ & $34.7 \pm 10.9$ \\
$\begin{array}{l}\text { Length of stay in } \\
\text { hospital (hr) }\end{array}$ & $9.05 \pm 3.11$ & $98.2 \pm 14.1$ & $69.3 \pm 9.0$ \\
\hline
\end{tabular}

Data are mean \pm SD.

TABLE II Baseline anxiety scores

\begin{tabular}{llll}
\hline & $\begin{array}{l}\text { Group I } \\
(60 \mathrm{~min})\end{array}$ & $\begin{array}{l}\text { Group II } \\
(90 \mathrm{~min})\end{array}$ & $\begin{array}{l}\text { Group III } \\
\text { placebo }\end{array}$ \\
\hline STAI trait & $32.5 \pm 9.4$ & $34.0 \pm 11.7$ & $34.4 \pm 10.4$ \\
STAI state T1 & $33.7 \pm 11.6$ & $35.3 \pm 15$ & $36.2 \pm 13.6$ \\
VAS T1 & $2.7 \pm 1.6$ & $3.5 \pm 2.6$ & $3.8 \pm 2.1$ \\
\hline
\end{tabular}

Data are mean \pm SD. STAI $=$ state-trait anxiety inventory; VAS = visual anologue score.

non-invasive blood pressure monitoring and end-tidal $\mathrm{CO}_{2}$ monitoring. Analgesia was provided with diclofenac sodium $100 \mathrm{mg}$ rectally after induction and morphine $0.1 \mathrm{mg} \cdot \mathrm{kg}^{-1}$ was given intramuscularly in the recovery area if needed.

\section{Statistical analysis}

Assuming a 0.05 level of significance and a power of 0.8 , standard power analysis revealed that approximately 15 patients per group would be required to detect a $50 \%$ reduction in the expected stress response (VAS of 50 approximately). All quantitative data are expressed as mean \pm SEM unless otherwise stated. The data were analyzed by one-way analysis of variance and subsequently, where appropriate, by paired analysis.

\section{Results}

Sixty-one patients completed the study. One patient was excluded as she required admission to the hospital overnight for bleeding postcystoscopy.

Demographic data is illustrated in Table I. There was no significant difference between the groups for age, weight, duration of surgery or length of stay in hospital. The majority of the surgical procedures performed were arthroscopy, dilatation and curettage and varicose vein ligation. 


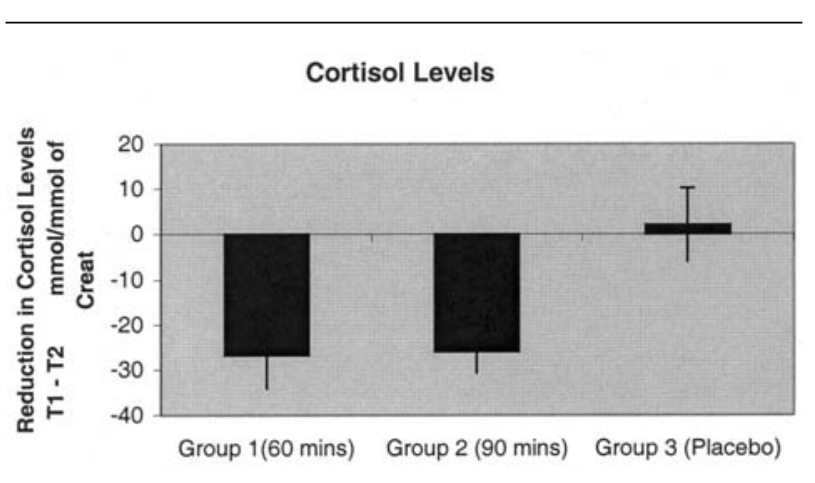

FIGURE 1 Reduction in cortisol levels T1-T2 $\mathrm{mmol} / \mathrm{mmol}$ of creat. ${ }^{*} P<0.01$.

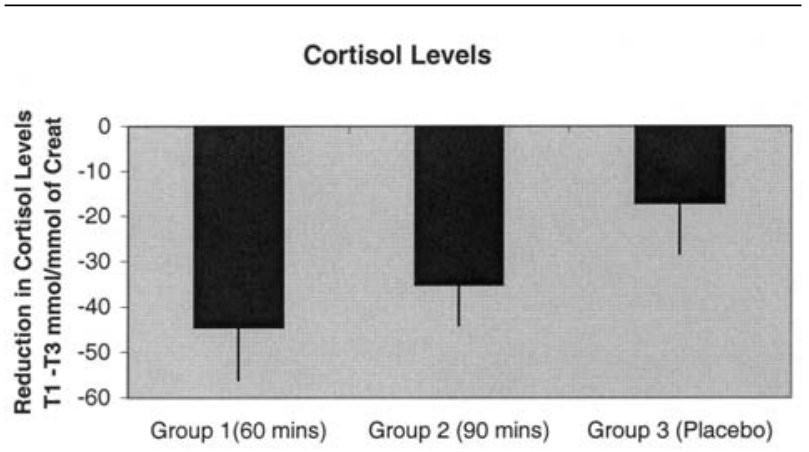

FIGURE 2 Reduction in cortisol levels Tl-T3 mmol/mmol of creat. ${ }^{*} P<0.05$

\section{Anxiety scores}

Baseline VAS anxiety scores were similar in the three groups (Table II). There was no significant difference in anxiety scores (VAS and STAI state scores) between the treatment groups and placebo group at T2 and T3.

\section{Urinary cortisol levels}

Baseline cortisol levels were similar in all three groups. There was a significant reduction in cortisol levels between $\mathrm{Tl}$ vs $\mathrm{T} 2$ and $\mathrm{T} 1$ vs $\mathrm{T} 3$ in both treatment groups compared to placebo (Figures 1 and 2 ).

\section{Urinary catecholamine levels}

There was no significant difference in urinary adrenaline or dopamine levels at any time point between the treatment and placebo groups. Baseline urinary noradrenaline levels were comparable between the three groups. There was no significant difference in actual noradrenaline levels at T2 or T3 between the groups.
However there was a significantly greater reduction in noradrenaline levels from T1 to T2 $(P=0.02)$ in Group I compared to placebo but this reduction in noradrenaline levels from $\mathrm{T} 1$ to $\mathrm{T} 2$ was not seen in Group II.

\section{Discussion}

The need for premedication in daycase patients has been controversial. Our study investigated the effect of benzodiazepine premedication on the stress response in patients undergoing daycase anesthesia and surgery. There was a statistically significant reduction in urinary cortisol from baseline levels to T2 and $\mathrm{T} 3$ in the groups receiving diazepam, and a statistically significant reduction in urinary noradrenaline from baseline levels to T2 in one group receiving diazepam.

Anxiety is a highly unpleasant emotion and undesirable consequence of surgery. Reduction of levels of anxiety is not only important for patient comfort, but may also decrease complications and improve the success of, and recovery from, surgery. ${ }^{9}$

The administration of diazepam instead of placebo resulted in a significant reduction in urinary cortisol levels in the treatment groups and also the urinary noradrenaline levels in Group I. This demonstrates in an objective manner a reduction in stress hormones which has been shown to be advantageous to patients undergoing surgery.

Daycase surgery is known to elicit anxiety. ${ }^{10}$ Unlike in-patients, daycase patients have no time to settle down and get used to the hospital environment. In a busy day surgery ward there is rarely enough time for detailed psychological anxiety lowering techniques to be employed. We conclude that benzodiazepine premedication may play an important role in reducing the stress response to anesthesia and surgery in this population however further studies are warranted.

\section{References}

1 Warner MA, Shields SE, Chute CG. Major morbidity and mortality within 1 month of ambulatory surgery and anesthesia. JAMA 1993; 270: 1437-41.

2 White PE. Comparative evaluation of intravenous agents for rapid sequence induction- thiopental, ketamine, and midazolam. Anesthesiology 1982; 57: 279-84.

3 Burn JMB. A blueprint for day surgery. Anaesthesia 1979; 34: 790-805.

4 Mackenzie JW. Daycase anaesthesia and anxiety. A study of anxiety profiles amongst patients attending a Day Bed Unit. Anaesthesia 1989; 44: 437-40.

5 Beechey APG, Eltringham RJ, Studd C. Temazepam as premedication in day surgery. Anaesthesia 1981;36: $10-5$. 
6 Reinhart K, Dallinger-Stiller $G$, Dennhardt $R$, Heinemeyer $G$, Eyrich $K$. Comparison of midazolam, diazepam and placebo i.m. as premedication for regional anaesthesia. Br J Anaesth 1985; 57; 294-9.

7 Fell D, Derbyshire DR, Maile CJD, et al. Measurement of plasma catecholamine concentrations. An assessment of anxiety. Br J Anaesth 1985; 57: 770-4.

8 Spielberger CD, Gorsuch RL, Lushene R, Vagg PR, Jacobs GA. Manual for State-Trait Anxiety Inventory. Palo Alto, CA: Consulting Psychologists Press Publishers, 1983.

9 Spielberger CD, Auerbach SM, Wadsworth AP, Dunn TM, Taulbee ES. Emotional reactions to surgery. J Consult Clin Psychol 1973; 40: 33-8.

10 Goldmann L, Ogg TW, Levey AB. Hypnosis and daycase anaesthesia. A study to reduce pre-operative anxiety and intra-operative anaesthetic requirements.

Anaesthesia 1988; 43: 466-9. 